\title{
Melissopalynological and physico-chemical analysis of honey from the beekeeping cooperative of Toumodi (Côte d'Ivoire)
}

\author{
Chimène KAUDJHIS ASSI ${ }^{1}$, Gbouhoury Eric-Kevin BOLOU² \& Salimata OUATTARA ${ }^{1}$ \\ ${ }^{1}$ Botanical research unit, U.F.R. Biosciences, Felix Houphouet-Boigny University of Cocody, 22 BP 582 \\ Abidjan \\ ${ }^{2}$ Centre National de Floristique (CNF) of Félix Houphouët-Boigny University (Ivory Coast) \\ Correspondent: 22 BP 582 Abidjan 22 (Ivory Coast); 22 BP 295 Abidjan 22 (Ivory Coast); Mobile: (225) 0839 \\ 44 19; E-mail: kaudjhischimene@yahoo.fr \\ DOI: 10.29322/IJSRP.11.02.2021.p11048 \\ http://dx.doi.org/10.29322/IJSRP.11.02.2021.p11048
}

\begin{abstract}
One of the means of reducing poverty in our societies could be beekeeping. For this, the products of the hive must be competitive. The objective of this study is to characterize and verify the floral origin of the honey sold by the Toumodi beekeeping cooperative. The sampling brought the honey intended for sale. The treatment of the samples for pollen analysis was done by acetolysis [1]. The parameters taken into account for the physicochemical analysis are density, $\mathrm{PH}$, water content, ash content, total sugar content (brix degree), electrical conductivity, and total acidity. The values obtained were compared with those recommended by the Codex Alimentarius. The honey from the Toumodi cooperative is multifloral and contains a large number of pollen which confirms its geographical origin, namely the forest-savanna transition zone. They meet international standards and are of good quality.
\end{abstract}

Index Terms- Honey, quality, pollen, analysis, Côte d'Ivoire.

\section{INTRODUCTION}

Côte d'Ivoire enjoys a favorable climate for agriculture, which is the mainstay of its economy. Agricultural activity currently employs $46 \%$ of the active population and is a source of income for two thirds of the population which is $50.3 \%$ rural [2]. Nevertheless, the poverty rate is increasing. According to [3], it has risen from 37 percent in 1995 to nearly 50 percent in recent years. This situation is due among other things to the reduction of available land, lower agricultural yields, fluctuating commodity prices and the consequences of climate change. To overcome this, the integration of young people in new economic activities is becoming essential. In this context, some young people are working to add value to the products of the hive. Moreover, honey production can easily be associated with other agricultural activities [4] ; [5]. Honey has been prized by men since ancient times for its mystical powers and its therapeutic, nutritive and cosmetic virtues. Beekeeping is an activity that generates significant additional income for farmers [6]. According to [7], it is a branch of agriculture which aims to raise bees in order to obtain in a profitable way products of the hive (honey, royal jelly, pollen, wax). It contributes to the development and protection of the environment [8]; [9]. Honey is highly sought after. As supply does not cover demand, it is more and more exposed to fraud attempts. This is why honeys imported by developed countries are more and more demanding; they have a preference for hive products bearing the information proving that they comply with the international standards of the Codex Alimentarius. These documents reveal the traceability of origins and the quality of the products intended for sale. Thus, to make them more competitive on international markets, honeys must be characterized.

Melissopalynology classifies the products of the hive by identifying their pollen. In revealing the botanical and geographical origins of these products, this technique makes it possible to guarantee the food quality of honey for the consumer as well as for producer. In Côte d'Ivoire, very few studies have addressed quality and pollen content of honey: [10] and [11] analyzed some honey samples, respectively of Dimbokro and Yamoussoukro; [12] compared the quality of some samples of local honeys to imported honeys [13] has analyzed some honey samples from Katiola. With its vegetation made up of both forest and savannah species and various crops, Toumodi has a lot of mellifer potentiality [14]. But to date, no study has yet been carried out both on the botanical origin and on the quality of the honey of this department. This work is part of the promotion of honey from the association of beekeepers in the department of Toumodi. It aims to characterize the honey they collect. Specifically, this involves carrying out the pollen analysis of samples of Toumodi honey to verify its botanical origin, confirm its geographical origin and evaluate its quality by physico-chemical analysis. 


\section{MATERIALS AND METHODS}

\section{II.1. Study environment}

Toumodi Department is located in central Côte d'Ivoire in the southern part of the Baoulé "V" in the forest-savanna contact zone (Figure 1). The Baoulé " $\mathrm{V}$ " is characterised, in climatic terms, by a transition between a humid tropical climate in the south and a dry tropical climate in the north [15]. The average temperature is about $26^{\circ} \mathrm{C}$ [16]. Rainfall averages $1200 \mathrm{~mm} /$ year. The region is dominated by wooded savannah vegetation, with a high density of shrubs sometimes overhung by tall trees, such as the cheese makers: Ceiba pentandra (Malvaceae). The vegetation around the apiaries concerned by the study includes 157 species of honey plants. These species belong to 157 genera and 42 plant families [14]. The population is made up of the de N'gban [17], to which are added non-native and non-native species. Their main activity is agriculture.

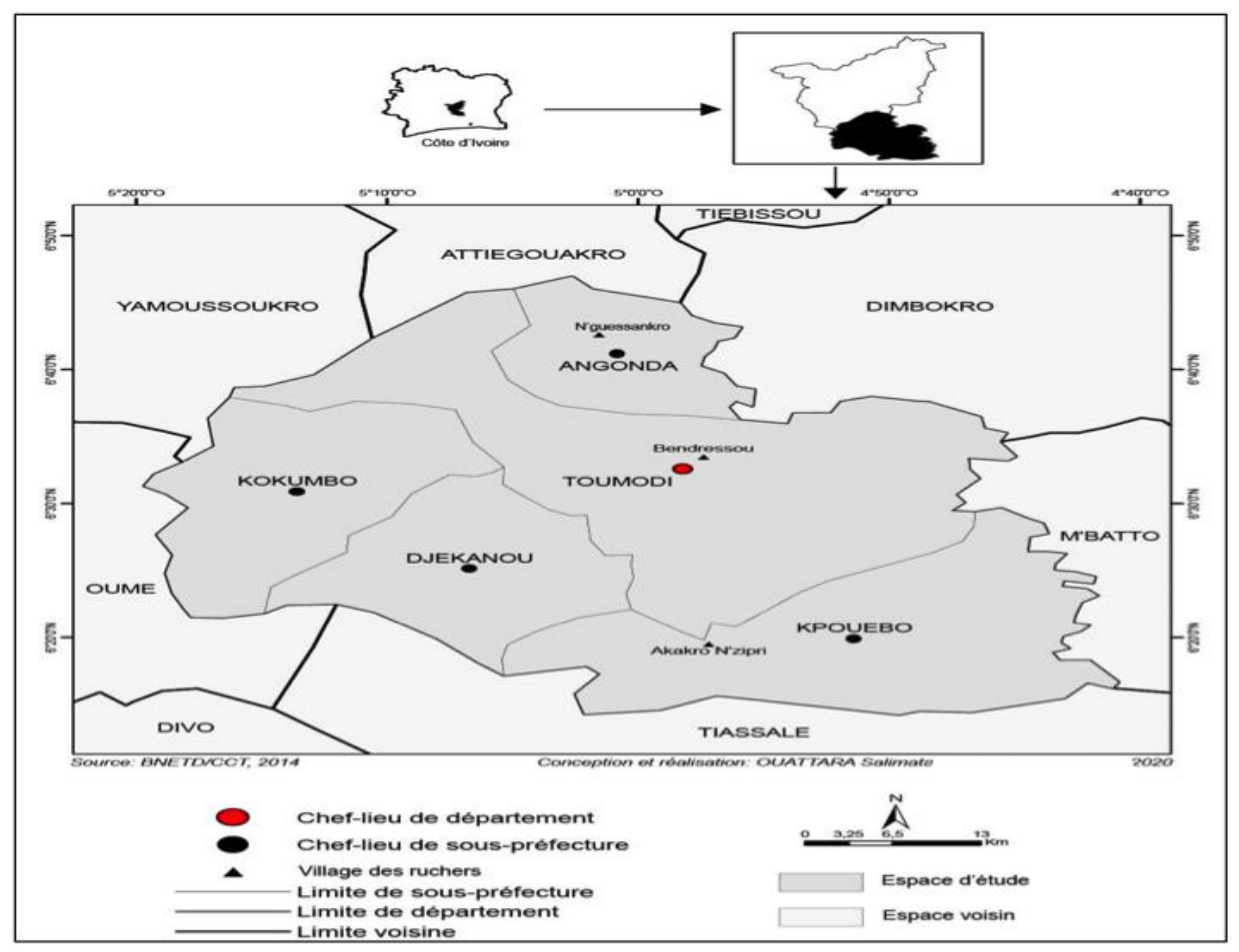

Figure 1. Map of Geographic Location of the Study Area

\section{2. Sampling}

Modern beekeepers in the Toumodi region have formed a cooperative and own three apiaries in three different localities : AkakroN'zikpri, N'guessankro and Bendressou. The honey collected in each of the apiaries is mixed before being bottled for sale. The analysis of this study was carried out on the product resulting from the 2020 harvests. The mechanical method is used for the extraction of honey.

\section{II.3. Methods}

Two types of analyses were performed: pollen analysis and physicochemical characterization.

\section{II.3.1. Melissopalynological analysis}

10 grams of honey were collected and processed according to the [1] method to extract pollen by leaching. The observation of pollen was carried out using a binocular photonic microscope (OPTIKA SN 455318). Different documents were used for pollen identification: the Pollen Atlas of Côte d'Ivoire [18] and the Atlas of Pollens of Tropical West African Flora by [19], the pollen database of the USO OREME Data Portal (https://data.oreme.org/observation/pollen). Depending on the pollen, the identifications were by family or genus, and also by species.

The pollen content (TP) of honey is calculated according to the following formula :

$\mathrm{TP}=($ Number of pollen counted $\times 1000 \times 10 \times \mathrm{d}) / 20$. 
The frequency of pollen grains was assessed according to the method of [20]. The relative frequency (FR), expressed as a percentage, was obtained by performing the number of pollen grains of a pollen type out of the total number of pollen grains counted in a preparation, according to the following formula:

$\mathrm{n}$ : Number of pollen grains counted for the taxon.

$\mathrm{N}$ : Total number of pollen grains counted.

$$
\mathrm{FR}=(\mathrm{n} / \mathrm{N}) * 100
$$

Thus, for :

- dominant and main pollen : FR $>45 \%$;

- accompanying pollen: $16<\mathrm{FR}<45 \%$;

- important isolated pollen: $3<\mathrm{FR}<15 \%$;

- rare or isolated pollen: FR $<3 \%$.

The assessment of the pollen content or richness was made according to Maurizio (1939) who has Classify honeys according to their pollen richness as follows:

- Class I or class poor: Pollen richness : < 20000 pollen grains /10 g dry matter ;

- Class II or Medium class: Pollen Richness 20000 pollen grains /10 g of dry matter $<$ Pollen Richness $<100000$ pollen grains /10 g dry matter ;

The Rich Classes are of three types

- Class III: 100,000 - 500,000 pollen grains /10 g dry matter,

- Class IV: 500,000 - 1,000,000 pollen grains /10 g dry matter

- Class V: greater than 1,000,000 pollen grains/10 g dry matter.

The relative frequencies were calculated on Excel software and represented by histograms.

\section{3. 2. Physico-chemical analysis}

This examination looked for the following elements: $\mathrm{pH}$, Density, moisture or humidity content, Brix degree or total sugar content, Ash content, Electrical Conductivity and Total acidity.

\section{Determination of $\mathrm{pH}$}

After diluting the $10 \mathrm{mg}$ honey samples by $1 / 10$, their $\mathrm{pH}$ was measured. This parameter informs the botanical origin of the honeys. According to [22], nectar honey has a pH between 3.5 and 4.5 and that of honeydew between 5 and 5.5 .

\section{Honey Density $(D)$}

The density was obtained by this formula :

M: density of honey, M': density of pure water

$$
\mathrm{D}=\mathrm{M} / \mathrm{M}^{\prime}
$$

\section{Determination of water content (Te)}

The water content was measured by a refractometer.

\section{Determination of brix degree (Ts)}

The brix degree is used to obtain the sugar concentration of the honey. The sugar content of each honey sample is a value determined by a refractometer set at a temperature of $20^{\circ} \mathrm{C}$.

\section{Ash content (Tc)}

Ash content was obtained by this formula :

$\mathrm{m}_{0}$ : mass in grams of empty capsules

$\mathrm{m}_{1}$ : mass in grams of test sample capsules

$\mathrm{m}_{2}$ : mass in grams of test sample capsules after incineration

$$
\mathrm{Tc}=\mathbf{m}_{2}-\mathbf{m o m}_{1}-\mathbf{m}_{\mathbf{0}} \times 100
$$




\section{Electrical Conductivity (Ce)}

Electrical Conductivity was measured by a Conductimeter.

Total acidity (meq/kg) : Ta

Total acidity was obtained by this formula :

$\mathrm{V}$ : Volume of soda or $\mathrm{NaOH}$ poured

TS: Test Sample of honey used

$$
\mathrm{Ta}=1000 * \mathrm{~V} * \mathbf{0}, \mathbf{0 5} \mathrm{TS} \times 10
$$

\section{1. Melissopalynological analysis}

\section{RESULTS}

\section{III.1.1. Quantitative analysis}

The qualitative analysis identified 65 pollen taxa, belonging to 34 botanical families. This number includes 27 isolated and important ones which has been counted at least 5 times. The richest families in number of species and genera are the families of Malvaceae with three species : (Ceiba pentandra and Bombax buonopozense and Adansonia digitata), the family Arecaceae with also three species: (Borassus aethiopium, Phoenix reclinata and Elaeis guineensis) and the family Combretaceae with three species: Terminalia macroptera, T. superba and Combretum sp. The number of pollen in 20 microliters of extract is on average 500.

The density of the honey is 1.41 . The pollen content of honey is on average 375000 . Honey is rich in pollen and its pollen content is classified in category III (figure 3).

\section{Table 1: Quantitative analysis}

\begin{tabular}{|l|l|l|l|l|}
\hline $\begin{array}{c}\text { Pollen counted in } \\
\mathbf{2 0} \text { microliters of } \\
\text { base }\end{array}$ & Density of honey & $\begin{array}{l}\text { Pollen content of } \\
\mathbf{1 0 g} \text { of honey }\end{array}$ & Class & $\begin{array}{l}\text { Pollen richness of } \\
\text { honey }\end{array}$ \\
\hline 532 & 1,41 & 375000 & Class III & Rich class \\
\hline
\end{tabular}

\section{III.1.2. Qualitative analysis}

The pollen spectrum of honey is represented by 27 pollen taxa (figure 2). Based on the frequency of occurrence of pollen taxa, two distinct categories of pollen taxa are distinguished: important isolated taxa $(3 \% \leq \mathrm{FR} \leq 15 \%)$ and rare isolated taxa $(\mathrm{FR} \leq 3 \%)$. The analyzed honey has no dominant taxa $(\mathrm{FR} \geq 45 \%)$. It is thus a polyfloral or all-flower honey. It also has no accompanying taxa $(16 \leq \mathrm{FR} \leq 45 \%)$ (Table 2$)$. 
Table 2: Category of pollen taxa of honey

\begin{tabular}{|l|l|l|}
\hline $\begin{array}{l}\text { Large isolated taxa } \\
\text { (FR } \geq \mathbf{3} \% \leq \mathbf{1 5 \% )}\end{array}$ & $\begin{array}{l}\text { Rare isolated taxa } \\
\mathbf{( F R}<\mathbf{3} \% \mathbf{)}\end{array}$ & Naming honey \\
\hline Acacia pennata & Alchornea cordifolia & Polyfloral honey \\
Asteraceae undiff & Allophylus africanus \\
Carica papaya & Anacardium occidentale \\
Ceasalpinia & Annona senegalensis \\
Elaeis guineensis & Bombax buonopozense & \\
Mangifera indica & Ceiba pentandra & \\
Parinari & Cissus populnea & \\
Parkia & Combretum & \\
Phoenix reclinata & Lantana camara & \\
Poaceae undiff & Lasiodiscos mildbradii & \\
Sygygium guineense & Paullinia pinnata & \\
Borassus aethiopium & Terminalia macroptera & \\
Autres pollen & Terminalia superba & \\
& Adansonia digitata & \\
\hline
\end{tabular}

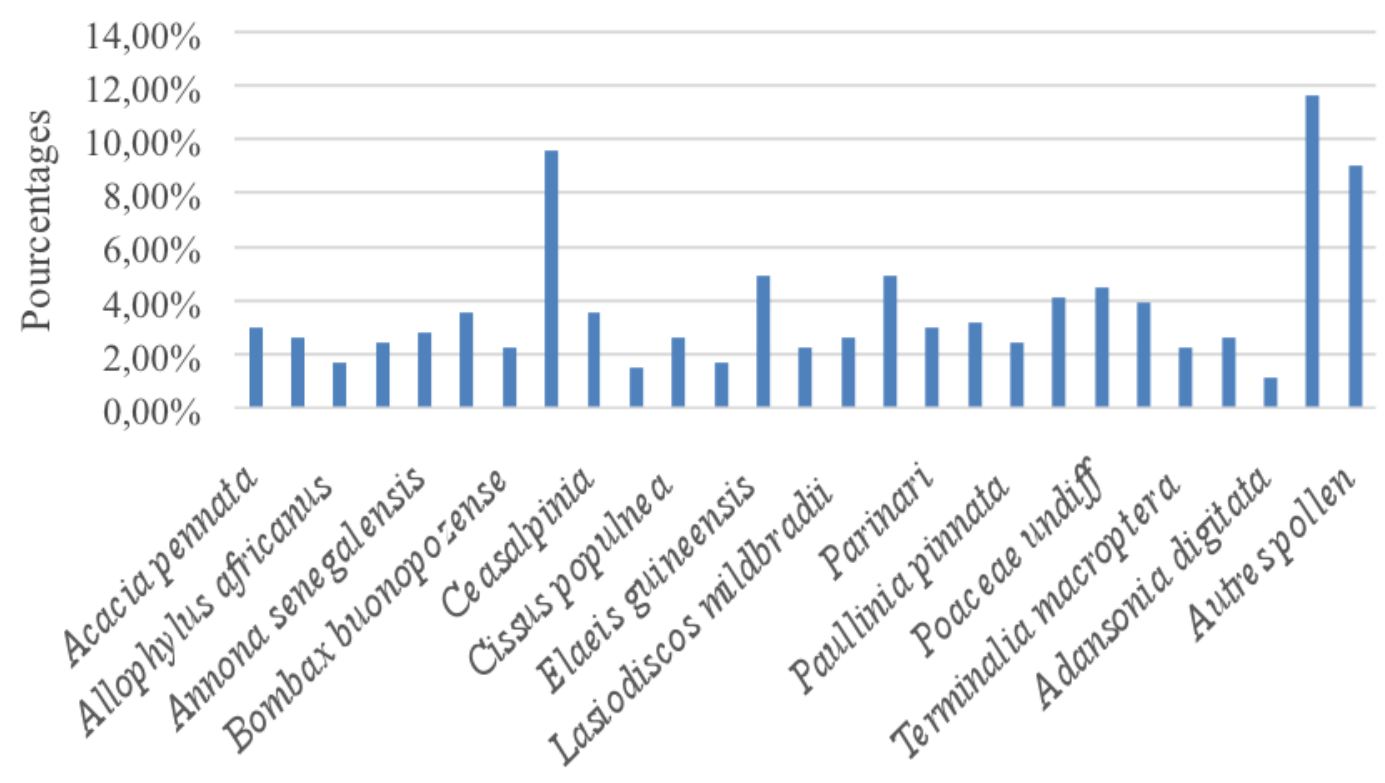

Taxons polliniques

Figure 2 : Pollen Spectrum 

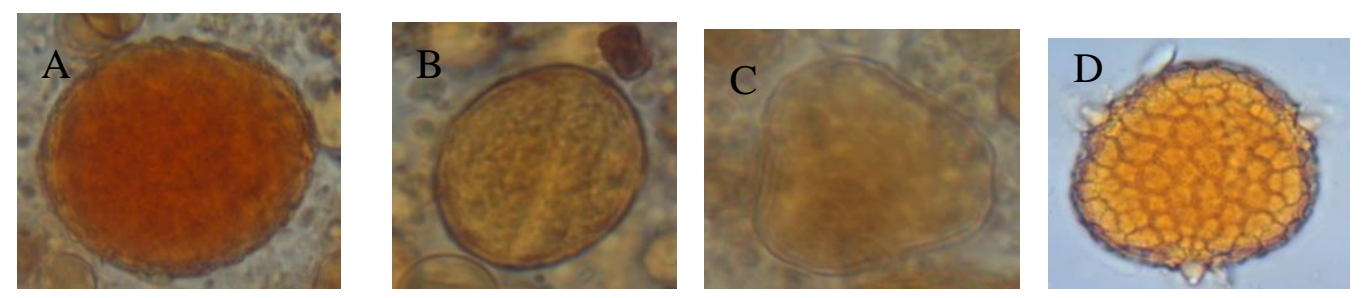

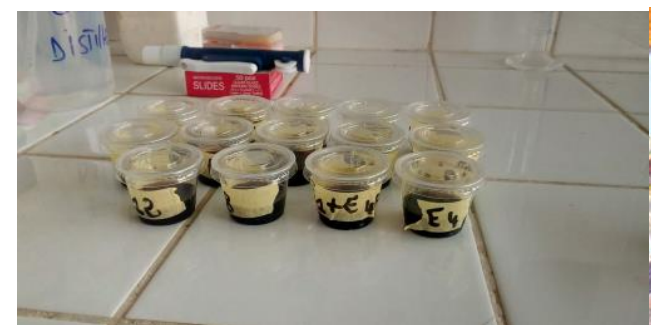

$\mathrm{E}$

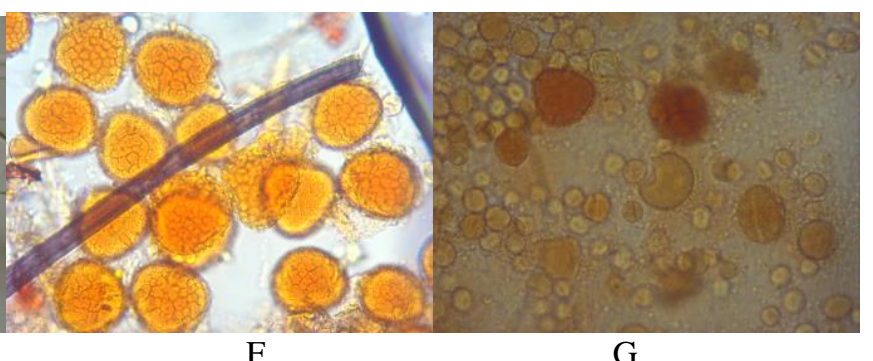

G

A : Ceiba pentandra (Malvaceae); B : Phoenix reclinata (Arecaceae)

$\mathrm{C}$ : Elaeis guineensis (Arecaceae) ; D : Bombax buonopozense (Malvaceae)

Figure 3. Samples of Toumodi honey (E); example of some pollen taxa and overview of the pollen content of the analyzed honey (F and G). Magnification x100.

\section{2. Physicochemical analysis}

The physicochemical analysis of honey is a quality analysis, it allows to evaluate the quality of honeys in relation to internationally recommended limit values. The determined physicochemical parameters of honey are recorded in the table 2 . The analyzed honey has a density of $1.41 \pm 0.01$. Its Hydrogen Potential $(\mathrm{PH})$ is $3.77 \pm 0.10$. Its Water Content $(\mathrm{Te})$ has a value of $17.02 \pm 0.02 \%$. Its Ash Content (Tc) is $0.05 \pm 0.01 \%$. Its Total Sugar Content (Ts) is $75.23 \pm 0.38 \%$. Electrical Conductivity $(\mathrm{Ce})$ is $268.00 \pm 0.00(\mu \mathrm{S} / \mathrm{cm})$ and Total Acidity (At) is $49.00 \pm 0.00 \mathrm{mEq} / \mathrm{Kg}$. All these physico-chemical parameters of the analyzed honey are in accordance with the honey standard of the Codex Alimentarius, apart from the total sugar content which is higher than the recommended limit i. e. $\leq 65 \%$ (Table 2). 
Table 3: Physico-chemical composition of Toumodi honey

\begin{tabular}{|c|c|c|c|c|c|c|c|}
\hline & \multicolumn{7}{|c|}{ Physico-chemical parameters } \\
\hline & Density & $\mathrm{PH}$ & $\operatorname{Te}(\%)$ & $\mathrm{Tc}(\%)$ & Ts $(\%)$ & $\mathrm{Ce}(\mu \mathrm{S} / \mathrm{cm})$ & $\begin{array}{l}\mathrm{Ta} \\
(\mathrm{mEq} / \mathrm{Kg})\end{array}$ \\
\hline Toumodi honey & $\begin{array}{l}1,41 \pm \\
0.01\end{array}$ & $3,77 \pm 0,10$ & $\begin{array}{l}17,02 \pm \\
0,02\end{array}$ & $\begin{array}{l}0,05 \pm \\
0,01\end{array}$ & $\begin{array}{l}75,23 \pm \\
0,38\end{array}$ & $\begin{array}{l}268,00 \pm \\
0,00\end{array}$ & $49,00 \pm 0,00$ \\
\hline \multirow[t]{2}{*}{$\begin{array}{l}\text { International } \\
\text { standard } \\
\text { (Codex, 2000 ; } \\
\text { 2001) }\end{array}$} & \multirow[t]{2}{*}{$\begin{array}{l}1,39- \\
1,44] \\
\text { general } \\
\text { case }\end{array}$} & $\begin{array}{l}{[3,5-4,5]} \\
\text { nectar } \\
\text { honey }\end{array}$ & \multirow[t]{2}{*}{$\begin{array}{l}\leq 21 \% \text { All } \\
\text { honeys } \\
\text { except } \\
\text { exception }\end{array}$} & \multirow[t]{2}{*}{$\begin{array}{l}\leq 0,6 \% \\
\text { All } \\
\text { honeys }\end{array}$} & $\begin{array}{l}\leq 65 \% \\
\text { nectar } \\
\text { honey }\end{array}$ & $\begin{array}{l}\leq 0,8 \mathrm{mS} / \mathrm{cm} \\
\text { or } \quad 800 \\
\mu \mathrm{S} / \mathrm{cm}, \\
\text { nectar } \\
\text { honey }\end{array}$ & \multirow[t]{2}{*}{$\begin{array}{l}\leq 50 \\
\mathrm{mEq} / \mathrm{Kg} \\
\text { All honey }\end{array}$} \\
\hline & & $\begin{array}{l}{[5-5,5]} \\
\text { Honeydew } \\
\text { honey }\end{array}$ & & & $\begin{array}{l}\leq 4 \% \\
\text { Honeydew } \\
\text { honey } \\
\leq 53 \% \\
\text { Honeydew } \\
\text { honey }\end{array}$ & $\begin{array}{l}\geq 1,2 \mathrm{mS} / \mathrm{cm} \\
\text { or } \quad 1200 \\
\mu \mathrm{S} / \mathrm{cm}, \\
\text { Honeydew } \\
\text { honey }\end{array}$ & \\
\hline
\end{tabular}

Te : water content; Tc : Ash content ; Ts : brix degree ; Ce : Electrical Conductivity; Ta: Total acidity.

\section{DISCUSSION}

\section{1. Melissopalynological analysis}

The pollen content of honey is the amount of pollen in 10 grams of honey [23]; [24]. This content is 375,000 grains of pollen for the Toumodi sample. According to the classes of honey recommended by [23] according to their pollen content, the honey studied belongs to class III. It is therefore a honey rich in pollen. It is a pollen-rich flower honey according to [24] The qualitative analysis identified 65 pollen taxa, including 27 isolated and important ones. The richness in pollen taxa of the Toumodi honey sample is close to those determined by [25] in the honeys collected in the localities of Séguéla: Forona (30 pollen taxa), Wongué (31 pollen taxa) and Daloa (25 pollen taxa). This richness in pollen taxa is also greater than that obtained by [26] in the samples of honey collected in the localities of northern Benin (4, 7 and 16 pollen taxa) and [25] in the locality of Bobi (15 pollen taxa) in Séguéla. The taxonomic richness of Toumodi honey also shows the melliferous diversity of the plants around the harvest apiary. However, this richness in pollen taxa is lower than that obtained by [13]: 85 pollen taxa in ten honey samples collected in the Department of Katiola and [10]: 206 pollen taxa in sixteen honey samples collected in the Department of Dimbokro. This difference could be explained by the amount of sample analyzed or by variations in harvest periods

\section{2. Physicochemical analysis}

The physicochemical analysis makes it possible to appreciate the quality of honeys thanks to the measurements of a certain number of parameters.

Honey with a density of $1.41 \pm 0.01$, this density is in conformity with the standard on the densities of honeys which is between 1.39 and 1.44 according to the Codex Alimentarius [27]. The value of the Density of honey gives indications on its water content. Indeed, a honey with a density included in the range recommended by the Codex, would have a water content lower than $21 \%$. Thus, the density of Toumodi honey confirms its water content.

The measurement of the $\mathrm{PH}$ allows to appreciate the level of acidity of honey and to determine the botanical origin of honeys. The PH of Toumodi honey is 3.77. This value is included in the acceptable PH range of the Codex Alimentarius standards which is between 3.5 and 4.5 for nectar honeys. [25] obtained $\mathrm{pH}$ close values (3.7-4.77) for Worodougou honeys in Côte d'Ivoire. From the therapeutic 
point of view, honeys with low $\mathrm{pH}$ better inhibit the growth and proliferation of microorganisms and thus have a better antibacterial power [28]. In addition, the variation of the $\mathrm{pH}$ of honeys would be due to the foraged flowers, the salivary secretion of the bee and the enzymatic and fermentative processes during the transformation of the raw material [29]. Therefore, the analyzed honey would have an acceptable acidity and would be a honey produced by bees only by foraging the flowers of honey plants. According to [30], the $\mathrm{pH}$ of honey is important during the extraction process, as it affects the texture of the honey, its stability and shelf life.

The water content of honey of $17.02 \pm 0.02$ is in accordance with the [27]. Moisture content is an important parameter for assessing the maturity of honey and also determines its shelf life. It conditions the fermentation and crystallization of honey. The analyzed honey would be a honey harvested at maturity and could be stored for long time without risk of fermentation, if the storage conditions are appropriate. According to [22], only honeys with a water content lower than $18 \%$ are good to keep without risk of adulteration.

The analyzed honey has an ash content of $0.05 \%$. This value conforms to the standard set by the Codex Alimentarius, where the ash content of honeys is less than or equal to $0.6 \%$ and in the range $(0.05 \%-1.5 \%)$ recommended by the Directive of the Council of the European Union [31]; [32]. The ash content makes it possible to appreciate the content of mineral substances in honey and undesirable minerals. That of the analyzed honey is acceptable and would not contain undesirable minerals.

The value of the sugar content of honey is 75.23. This value is on the other hand higher than the minimum value fixed at $65 \%$ for the sweetest nectar honeys [27]. This result is close to the values obtained by [33] in Algerian honeys: 62.5 and 90.12\% and those obtained by [11]: 74.0 and $81 \%$ in honeys from the Department of Yamoussoukro. These high sugar values in honeys could be explained by the sugar content of the nectars of flowers foraged by bees to make honey or by the environmental conditions of the production environment. According to [34], the sugar content of honey is a function of the sugar concentration of the nectars and the enzymes of the bees during elaboration. It is responsible for many physicochemical properties such as viscosity, hygroscopicity and crystallization [35].

The electrical conductivity of honey is $268 \mu \mathrm{S} / \mathrm{cm}$. The value obtained is within the range of values recommended by the Codex Alimentarius, which says that the electrical conductivity of nectar honeys is less than or equal to $0.8 \mathrm{mS} / \mathrm{cm}$ and those of honeydew honeys greater than or equal to this number. The electrical conductivity of honey makes it possible to test the mineral content of honeys and therefore replaces the ash content of honey during routine checks. It also makes it possible to determine the botanical origins of the honeys. The analyzed honey would be a flower honey or nectar honey.

The value of the total acidity of the honey is $49 \mathrm{mEq} / \mathrm{Kg}$. This value is less than that of the Codex Alimentarius [27] which is 50 $\mathrm{mEq} / \mathrm{Kg}$. This indicates the absence of undesirable fermentations in the honey. There is indeed a correlation between the $\mathrm{pH}$ of honey and acidity. The assessment of the acidity of honey is an important quality criterion because it gives important indications on the state of the honey [36].

\section{Conclusion}

The melissopalynological analysis of the honey of the beekeepers forming the Toumodi beekeeping cooperative is rich in pollen. The qualitative analysis identified 65 pollen taxa, belonging to 34 botanical families, including 27 isolated and important. The pollen content of the honey confirms its botanical origin. It is a multi-floral honey. The analyzed honey has a density of $1.41 \pm 0.01$. Its Hydrogen Potential is 3.77 \pm 0.10 . Its Water Content has a value of $17.02 \pm 0.02 \%$. Its Ash Content is $0.05 \pm 0.01 \%$. Its Total Sugar Content is $75.23 \pm 0.38 \%$. Electrical Conductivity is $268.00 \pm 0.00(\mu \mathrm{S} / \mathrm{cm})$ and Total Acidity is $49.00 \pm 0.00 \mathrm{mEq} / \mathrm{Kg}$. All these physico-chemical parameters of the analyzed honey are in accordance with the honey standard of the Codex Alimentarius, apart from the total sugar content which is higher than the recommended limit i. e. $\leq 65 \%$.

\section{REFERENCES}

[1] Erdtman G., 1969 : Pollen and spores preparations: the acetolysis method.In handbook of palynology, Munksgaard, Copenhagen, $213-216$.

[2] RGPH 2014. Recensement Général de la Population et de l’Habitat, résultat globaux. 24p.

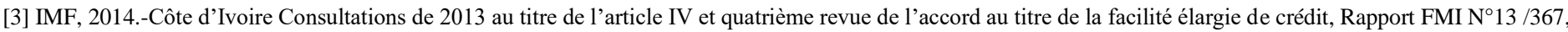
Côte d'Ivoire, $148 \mathrm{p}$.

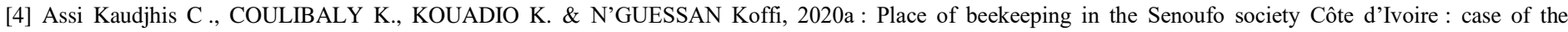
department of Korhogo (Côte d'Ivoire), Journal of Global Biosciences,Vol. 9, Number 10, pp. 8035-8048.

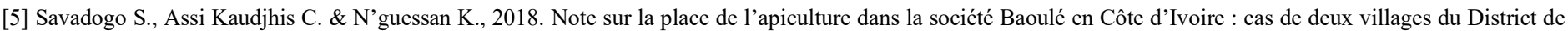
Yamoussoukro. Geo-Eco-Trop, 42, 1 : 199-206.

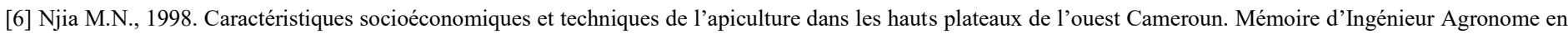
FASA (Option production animale), Université de Dschang, Dschang Cameroun, 75 p.

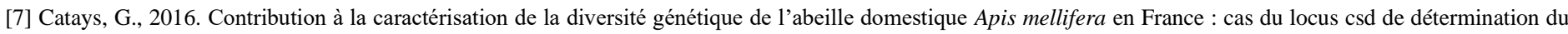
sexe. Thèse d'exercice, Médecine vétérinaire. Ecole Nationale Vétérinaire de Toulouse - ENVT. p 314. 
[8] Dushimimana J.D., 2007 : Rapport sur l'étude menée auprès des Apiculteurs autour du Parc National des Volcans. Rapport UNDP, Rwanda, 17 p.

[9] Amirat, A., 2014. Contribution à l'analyse physicochimique et pollinique du miel de Thymus algeriensis de la région de Tlemcen. Mémoire présenté pour l'obtention du diplôme de Master Académique. Université Abou-Bekr Belkaid -Tlemcen. $p 45$.

[10] Coulibaly S. 2014. Potentialités de production mellifère de la flore de transition forêt-savane, en zone guinéenne et caractérisations pollinique et physico-chimique de quelques miels de la côte d'ivoire (Afrique de l'ouest). Thèse présentée pour l'obtention du titre de docteur de l'université Félix Houphouët-Boigny en botanique, 194p.

[11] Iritie B. M., E. N. Wandan, Y. M. Yapi, N. C. Bodji, G. A. Mensah et A. Togbé Fantodji., 2014. Comparaison des caractéristiques physicochimiques des miels frais et âgés récoltés dans le rucher de l'arboretum de l'Ecole Supérieure Agronomique de Yamoussoukro en Côte d'Ivoire. Bulletin de la Recherche Agronomique du Bénin (BRAB). En ligne (on line) : 1840-7099.

[12] Djonwan F.D, 2018.Analyse physico-chimique comparative des miels locaux et importés commercialisés en Côte d'Ivoire. Thèse de doctorat, Université Félix Houphouët Boigny, Abidjan, Côte d'Ivoire, 72 p.

[13] Kouassi D. F., 2019. Diversité de la flore mellifère et importance du miel en zone savane subsoudanienne dans le département de Katiola (Centre nord de la Côte d'Ivoire). Thèse de doctorat. Université Felix Houphouet Boigny. Abidjan. Côte d'Ivoire. 192p.

[14] Assi Kaudjhis C ., KOUADIO K., Aké Assi E. \& N'GUESSAN Koffi, 2020b : Melliferous plant diversity in the forest-savanna transition zone in Côte d'Ivoire : case of Toumodi department. International Journal of Development Research,Vol 10, Issue 11, pp. 41819-41827.

[15] Gautier L., 1990 : Contact forêt-savane en Côte-d'Ivoire centrale: évolution du recouvrement ligneux des savanes de la Réserve de Lamto (sud du V-Baoulé). Candollea, 45(2), 627-641.

[16] Alla E. Y. G. H., 2011. Contribution à l'optimisation des résultats zootechniques d'une ferme ovine: Cas de la station de Toumodi, Université Nangui Abrogoua, Abidjan. Côte d'Ivoire. 24p.

[17] Bla K. B., Trebissou J. N. D., Bidié A. P., Assi Y. J., Zirihi-Guédé N., Djaman A. J., 2015. , Étude ethno pharmacologique des plantes antipaludiques utilisées chez les Baoulé- N'Gban de Toumodi dans le Centre de la Côte d'Ivoire. Journal of Applied Biosciences 85:7775-7783.

[18] Ybert J6P ,1979. Atlas de pollens de Côte d’Ivoire. Editions ORSTOM, N 40, 66p.

[19] Gosling W. D., Miller C. S., Livingstone D. A., 2013. Atlas des pollens de la flore tropicale Ouest Africaine. Revue de Paléobotanique et de Palynologie.199 : 1 135 .

[20] Louveaux J., Maurizio A. et Vorwohl C. 1970. Commission internationale de botanique apicole de l'U.I.S.B. Les méthodes de la mélissopalynologie. Apidologie, $1: 211-227$

[21] Maurizio A., 1939. Untersuchungen zur quantitativen pollen analyse des Honigs. Mitt. Geb. Lebensmittelunters. Hyg, 30, (1/2), 27-69.

[22] Gonnet M., 1982, Le miel : composition, propriétés, conservation. Editions Echouffour.

Argentan. Ornes ; 9-12 p.

[23] Maurizio A. 1968. La récolte et l'emmagasinage du pollen par les abeilles, In : Traité de Biologie de l'Abeille, Masson Ed, Paris, Tome III : 168-173.

[24] Randrianarivelo R H M. 2010. Application de l'analyse pollinique aux miels de différentes régions de Madagascar. Mémoire pour l'obtention du Diplôme d'Etudes Approfondies (D.E.A.) en Biologie et Ecologie Végétales. Université d'Antananarivo, 71p.

[25] Diomandé Massé, Coulibaly Siendou, Koko Anauma Casimir et Bohoua Louis Guichard. 2018. Identification de plantes mellifères et propriétés physico-chimiques des miels de la region du worodougou, Côte d'Ivoire. International Journal of Current Research Vol. 10, Issue, 04, pp.67583-67590.

[26] Lobreau-Callen D, Darchen R, Le Thomas A, 1986. Apport de la palynologie à la connaissance des relations abeilles/plantes en savanes arborées du Togo et du Bénin. Apidologie 17 : 279-306.

[27] Codex, 2001. Programme mixte FAO /OMS sur les normes alimentaires. Commission du Codex Alimentarius. ALINORM 01/25, p1-31.

[28] Julika, N.W., Ajit, A., Sulaiman, A.Z., Naila, A., 2019. Analyse physico-chimique et microbiologique du miel d'abeilles sans dent récolté sur le marché local en Malaisie. Indonésie Journal Chemical. 19 (2): 522-530.

[29] Louveaux J.1978. Composition, propriétés et technologie du miel. In: CHAUVIN R. Traité de biologie de l'abeille. Editions Masson et Cie, Paris, Tome 3, 277324 ;

[30] Rebiai A ; Lanez T ; Chouikh L. 2015. Physicochemical and biochemical properties of honeybee products in South Algeria.St. Cerc. St. CICBIA. 16 (2), 133-142.

[31] Bogdanov S, Ruoff K, Oddo PL, (2004): Physicochemical methods for the characterization of unifloral honeys. Apidologie 35. 17p.

[32] Rossant, A. 2011. Le miel, un composé complexe aux propriétés surprenantes. Nb thèse de doctorat, université de Limoge faculté de pharmacie. 32p. 


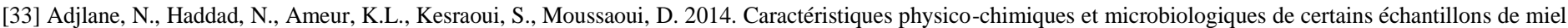
produits par les apiculteurs en Algérie. Acta Technol. Agric.17 (1): 1-5.

[34] Maurizio, A., 1959. Paper chromatographische untersuchungenan blutenhonigenUndlnekter. Ann. Abielle. 4:291-341.

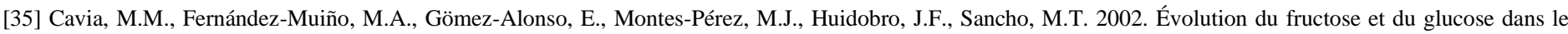
miel sur un an : influence de la granulation induite. Chimie alimentaire. 78(2): 157-161.

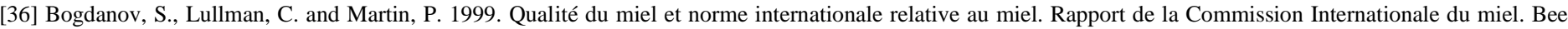
world 80:61-69.

\section{AUTHORS}

First Author - Chimène KAUDJHIS ASSI, Teacher-researcher, Botanical research unit, U.F.R. Biosciences, Felix HouphouetBoigny University of Cocody, kaudjhischimene@yahoo.fr.

Second Author - Gbouhoury Eric-Kevin BOLOU, Researcher, Centre National de Floristique (CNF) of Félix Houphouët-Boigny University (Ivory Coast), bgeric3@yahoo.fr.

Third Author - Salimata Ouattara, Student, Botanical research unit, U.F.R. Biosciences, Felix Houphouet-Boigny University of Cocody, salimataouattara1993@gmail.com

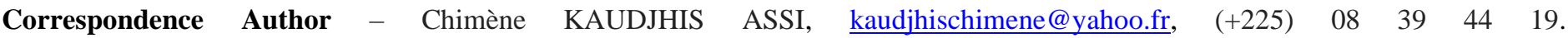

